\title{
Bog Spavin and Its Management in a Local Horse of Kashmir-a Case Report
}

\author{
Khadim Hussain Dar*, Shahid Hussain Dar and Beenish Qureshi \\ Division of Veterinary Surgery and Radiology, Faculty of Veterinary Sciences and Animal Husbandry, Shuhama, Alusteng, Sher-e-Kashmir University of \\ Agricultural Sciences and Technology, Kashmir-190006, India
}

Received: February 04, 2016; Accepted: April 05, 2016; Published: April 16, 2016

*Corresponding author: Khadim Hussain Dar, Division of Veterinary Surgery and Radiology, Faculty of Veterinary Sciences and Animal Husbandry, Shuhama, Alusteng, Sher-e-Kashmir University of Agricultural Sciences and Technology, Kashmir-190006, India, E-mail: drkhadim23@gmail.com

\begin{abstract}
A 4 year old stallion weighing $230 \pm 2.5 \mathrm{~kg}$ with the complaint of swelling of talocrural joint and left hind limb lameness for last 14 days. Based on the case history, clinical sign, and response to a flexion test the animal was confirmed as having the bog spavin. The case was managed with anti-inflammatory drug therapy and pressure bandaging. The animal recovered successfully. There was no reoccurrence of swelling upto 6 months when last examined indicating the complete recovery.
\end{abstract}

Keywords: Bog Spavin; Horse; Pressure bandaging

\section{Introduction}

Bog spavin, tarsal hydrathrosis or talocrural effusions is a distention of the joint capsule of the talocrural articulation as a result of chronic synovitis [1]. It is more commonly seen in younger horses, although it can occur in horses of any age and can affect one or both hocks [2]. The bog spavin is recognised by three characteristic fluctuating swellings [3]. The largest of the three swellings is situated dorsomedially at the level of medial side of the talus and two smaller distensions located one on either side at the posterior surface of the hock. These swellings vary in size depending on the severity of the underlying cause [4]. Bog spavin may be associated with lameness which can range in degree from mild to severe depending on the cause [5]. In horses younger than three years of age, most cases of bog spavin are caused by an osteochondrosis of joint talocrural, while in older and fully mature horses; it is most likely because of chronic strain of the joint capsule [1]. This case report presents the diagnosis and successful management of bog spavin in a local horse of Kashmir.

\section{History and Observations}

A 4 year old stallion weighing $230 \pm 2.5 \mathrm{~kg}$ was referred to Teaching Veterinary Clinical Services Complex, faculty of Veterinary Sciences and Animal Husbandry, SKUAST-Kashmir with the complaint of swelling of talocrural joint and left hind limb lameness for 14 days. Clinical examination revealed distended, soft fluctuant acute swelling on the dorsomedial side of talocrural joint as well as of the medial and lateral planter pouches (Figure
1). The horse was lame on the left hind limb (score 3 as per AAEP scoring system) and evinced pain while palpating at the talocrural joint and response to a flexion test was negative. Orthodiagnal radiographic views of talocrural joint showed enlarged joint space filled with a fluid with no bony changes. The vital signs such as temperature, pulse and respiratory rate were within normal physiological range.

\section{Diagnosis}

Diagnosis of bog spavin was done on the base of typical clinical signs that is three characteristic fluctuating distensions of the talocrural joint. However the radiographs of the hock joint didn't show any abnormality. Based on the case history, clinical signs, and response to a flexion test the animal was confirmed as having the bog spavin due to trauma.

\section{Treatment and Management}

From the affected joint after shaving and through scrubbing around $14 \mathrm{ml}$ of serous fluid was drained with use of 2 inch long 20 gauge sterile needle (Figure 2). The animal was than administered $2 \mathrm{ml}$ isoflupredone acetate intra-articularly and same was repeated after one week. The pressure bandage was applied around the hock joint for 21 days (Figure 3). The horse was than administered $12 \mathrm{ml}$ phenyl Butazone Intramuscularly (IM) once a day for five alternate days. Removal of pressure

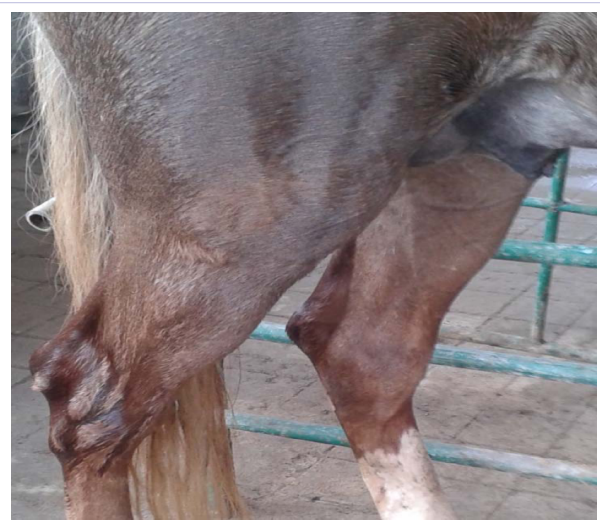

Figure 1: Swelling on anterio medial side at left hock joint. 


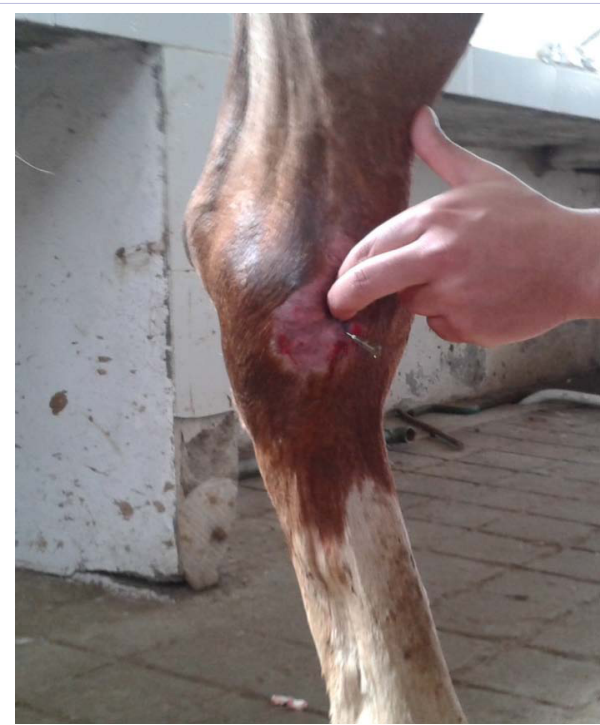

Figure 2: Straw colored fluid through needle at hock joint.

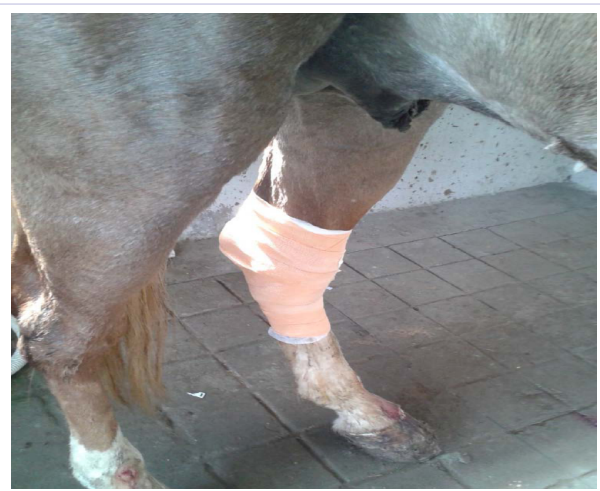

Figure 3: Pressure bandaging done on hock joint.

bandage at $22^{\text {nd }}$ day did not revealed any fluctuant swellings of the affected joint. The animal was examined again on $28^{\text {th }}$ day and there was no re-occurrence of swelling upto 6 months when last examined indicating the complete recovery.

\section{Discussion}

Bog spavin is generally an indication of underlying pathology within the joint and possible causes include synovitis, degenerative joint disease, or excessive strain of the joint capsule [2]. The unilateral case is more likely to be sequelae of sprain or chip fracture in the tarsus or osteochondritis dissecans lesions associated with the cranial intermediate ridges of digital tibial and lateral trochlear rides of the tibial tarsal bone [6]. The deficiency of calcium, phosphorous, vitamin A and vitamin $\mathrm{D}$ alone or in any combination can apparently produce the bog spavin [1]. Bog spavin is a physical finding, and does not directly cause lameness, however sign that horse has joint disease, which is a very significant finding. Usually lameness will occur if the work load of the horse is increased [7]. In the present case radiography didn't revealed any abnormal findings in the hock joint thus ruled out bone spavin from bog spavin [8].
Depending on the cause of the bog spavin, several treatments are available and if the condition is caused by traumatic injury (most commonly a 'strain') and there is no associated lameness, rest and some anti-inflammatory medication is all that is needed [5]. Intra-articular injection of corticosteroids decreases formation of excess fluid these cases [2]. However, best results are obtained by counter pressure following corticosteroid administration $[2,9]$. Infection of joint causes severe synovitis and should be treated as an emergency [8]. The present case report described the diagnosis of bog spavin and its successfull treatment with corticosteroid and pressure bandaging. [5]. Intraarticular injection of corticosteroids decreases formation of excess fluid in these cases [2]. However, best results are obtained by counter pressure following corticosteroid administration $[2,9]$. Infection of joint causes severe synovitis and should be treated as an emergency [8]. The present case report described the diagnosis of bog spavin and its successful treatment with corticosteroid and pressure bandaging.

\section{Conclusion}

Bog spavin should not be treated lightly, as the infection of joint can cause severe synovitis and therefore it's in best interest of the horse and owner to find the cause and treat the same even if the horse does not show lameness.

\section{Acknowledgement}

The authors are highly thankful to Dr. HU Malik, Professor and Head, Division of Teaching Veterinary Clinical Services Complex F.V.Sc \& A.H, SKUAST-K, for his persistent, valuable guidance and close supervision.

\section{References}

1. Pothiappon P, Parthiban S, Sivasudharsan. Bog spavin and its management in a in a Kathiawari Horse. Intas Polivet. 2012;13(2):291292.

2. Stashak TS. Adams lameness in horses. $4^{\text {th }}$ Ed. Boltimore: Willium and Wilkins; 1987. p. 357-360.

3. Gill HE. Diagnosis and treatment of hock lameness. Proc. AAEP. 257. 1973.

4. Venugopalan A. Essentials of Veterinary Surgery, $8^{\text {th }}$ Ed. India: Oxford and IBH Publishing Company Pvt Ltd; 2009. p. 257-258.

5. Sullins KE. The tarsus and Tibia. In Adams and Stashak's lameness in horses. $6^{\text {th }}$ Ed. Editor Baxter GM. Wiley and Blackwell; 2011. p. 11091204.

6. Kahn CM. Musculoskeletal system. In: the Merk veterinary manual. Kahn CM. $9^{\text {th }}$ Ed. NJ USA: Merk \& Co., INC white house station; 2005. p. 844-874.

7. Christine K, Richard, M. Equine Lameness. Equine Research Inc; 1997. p. 835-836.

8. Dyson SJ, Ross MW. Diagnosis and management of lameness in the Horse. $2^{\text {nd }}$ Ed. Elsevier Saunders; 2003. p. 508- 526.

9. Van Pelt RW, Riley WF. Therpautic managent of tarsal hydrarthrosis (bag spavin) in the horse by inta-articular injection of prednisolane. J Am Vet Med Assoc. 1967;15:328. 